DOI 10.31392/NPU-nc.series15.2021.6(137).02

Golubeva V.

teacher of the department of physical education Mykhaylenko V. senior lecturer at the Department of Physical Education Nazymok V. senior lecturer at the Department of Physical Education National Technical University of Ukraine Igor Sikorsky Kyiv Polytechnic Institute

\title{
PECULIARITIES OF USING MODERN INNOVATIVE TECHNOLOGIES IN THE PROCESS OF PHYSICAL EDUCATION OF STUDENTS
}

The article reveals the peculiarities of the use of modern information technologies in the process of physical education classes for student youth. Modern fitness programs and fitness bracelets were analyzed, which made it possible to investigate the impact of modern technologies on the popularity of physical education and physical activity among modern youth and there is an increase in motivation to exercise. Therefore, the introduction of modern information technologies in the education system, which provide further improvement of the educational process, preparation of the younger generation for life in the information space, becomes important. The introduction of infocommunication technologies in the educational process can not only increase the efficiency of the learning process, but also form a physical culture, which increases motivation to exercise, lead a healthy lifestyle, physical improvement, improve the level of physical activity.

They will allow you to capture data from various sensors, display indicators on a color display, store information in cloud storage. The result of such devices will be a bio-journal with data on the state of physical fitness of a particular student. The device measures body temperature, heart rate, blood pressure, oxygen content, monitors sleep phases and stress levels, and has a fairly wide range of functionality: speedometer, altimeter, pedometer, calorie counter.

Therefore, there is a question in the development and implementation of a system of control and evaluation of physical activity, which would meet the modern requirements of the educational process and have an effective impact on improving the status of physical education and attracting young people to exercise.

Key words: information and communication technologies, fitness programs, students, physical education, physical activity, physical exercises.

Голубєва В., Михайленко В., Назимок В. Особливості використання сучасних інноваційних технологій в процесі занять з фізичного виховання студентів. В статті розкрито особливості використання сучасних інфрормаційних технологій в процесі занять з фізичного виховання студентської молоді. Проаналізовано сучасні фітнеспрограми, фітнес-браслети, що дало можливість дослідити вплив сучасних технологій на підвищення рівня популярності фізичного виховання та рухової активності серед сучасної молоді та спостерігається підвищення рівня мотивації до занять фрізичними вправами.

Ключові слова: інформаційно-комунікаційні технології, фрітнес-програми, студенти, фізичне виховання, рухова активність, фрізичні вправи.

Formulation of the problem. One of the main criteria for the development potential of modern society is good health and a high level of physical fitness. Education and comprehensive training of professionals of new quality is possible only with the help of modern methods based on the latest advances in information technology.

The general tendencies of informatization of society and education in general could not but affect the sphere of physical culture and sports in higher education institutions, which contributed to the improvement of the educational process on the basis of the use of modern computer information technologies. After all, the use of innovative technologies in the process of physical education of student youth not only optimizes the educational process, but also improves motivation to exercise, promotes quality learning, and more.

Therefore, the introduction of modern information technologies in the education system, which provide further improvement of the educational process, preparation of the younger generation for life in the information space, becomes important.

Analysis of literature sources. Both domestic and foreign scientists, in particular, V. Osadchy, T. Koval, P. Samoilenko, O. Spirin, B. Shevel, V. Bykov, A. Rovny and others are actively engaged in the problems of informatization of education.

Information technology in physical culture is actively used for educational purposes. There are many educational technologies by which an untrained person can study various sports, martial arts, can get enough information necessary for training. Programs that allow you to visualize the process under study on the monitor screen have become widespread. With the help of such software, the user gets the opportunity to study the object in detail, taking into account the temporal and spatial motion of the process.

Thanks to these technologies, it is possible to increase the effectiveness of training and education in a relatively short time.

During this time the main directions of research works in pedagogy, psychology, sociology, medicine, technical sciences have been introduced. These studies represent both methodological, fundamental, research and experimental, and technical and technological, software and hardware developments in the field of educational informatization [4].

Presentation of the main research material. However, in modern conditions, physical education classes are not of interest to students, since school years, the attitude and motivation of young people to physical activity is deteriorating every year [2].

The impact of information and computer technology is becoming so great that it often forces modern youth to limit their 
interaction with reality and immerse themselves in the virtual electronic world. They begin to live and think in terms of the world created by the media, videos and computer games [1].

In recent years, a new direction related to the informatization of education has appeared in pedagogical science. The main task of this area is the process of providing the field of education with methodology, technology and practice of developing the optimal use of modern infocommunication technologies focused on the implementation of psychological and pedagogical goals of teaching and education [3].

Nowadays, motivational and value orientations in general and physical education in particular are largely formed through audiovisual means, mainly through television, videos, and the Internet [3].

To increase the effectiveness of the perception of educational material related to motor activities, various forms and means of presenting theoretical information are extremely important, and the technologies of interactive interaction used to promote motivation for independent educational activities and cognitive activity [4].

The introduction of infocommunication technologies in the educational process can not only increase the efficiency of the learning process, but also form a physical culture, which increases motivation to exercise, lead a healthy lifestyle, physical improvement, improve the level of physical activity.

It is known that modern computer technology provides an opportunity to organize the process of physical education at a higher quality level, allow to combine the functions of accumulation, storage, analysis, systematization of information and assessment of physical fitness of those involved, to implement an individual approach to physical education modern computer technology and, in particular, personalization of recommendations for correction, for example, the identified gaps in physical fitness, etc. An urgent issue in European countries is the creation of information data banks in higher education institutions, which provide an opportunity to systematize information about the level of health of student youth, their physical development, physical fitness, level of physical activity. Such data banks will allow to analyze the results of pedagogical influences on the principle of feedback and adjust them [3].

Informatization of education is a process of providing it with methodology and practice of development and optimal use of modern information technologies.

Introduction of new information technologies of training can solve the most various tasks: the message of knowledge, the control over a course of their mastering, demonstration of performance of exercises both statistical, and dynamic character; comparison of biomechanical characteristics of the standard of motor actions performed by the student, and instructions for further training depending on the identified differences with the standard; storage of information in the form of data banks with lesson plans, planning documents, files of mobile games, bibliographies, training and control programs, sets of general developmental exercises; control, accounting and analysis of the dynamics of physical development of students; maintaining documentation and processing the results of sports competitions; etc. The use of information computer technology in teaching significantly affects the motivational sphere of student youth, leading to the formation of priority learning motives that ensure the success of mastering knowledge and skills that contribute to the health of students, improve their physical health, physical fitness [1] .

Acceleration of scientific and technological progress, based on the introduction of flexible automated systems, microprocessors and software control devices, robots and machining centers, posed an important task for modern pedagogical science - to educate and prepare the younger generation able to actively participate in a qualitatively new stage of modern development. society associated with informatization.

As a result of the process of integration of computer technologies into the education system, modern information and communication technologies are increasingly used as a means of intensifying the educational process, in particular, physical education in higher education institutions.

The use of information and communication technologies in physical education classes allows to make the educational process mobile, strictly differentiated and individual, and for the teacher they are a source of educational information, visual aid, simulator, means of preparation and storage of tests, diagnostics and control [2].

Computer learning technologies, the latest teaching aids and the introduction of computerized management of the pedagogical process can transform learning from physical education into a highly productive, motivated and innovative process [3]. Monitoring research in the field of physical culture and sports is accompanied by obtaining a large array of operational information, the analysis of which is impossible without the use of modern information systems [1].

A great help in preparing and conducting physical education classes for teachers is provided by the Microsoft Office package, which includes, in addition to the well-known Word word processor, also an Access database system and electronic Power Point presentations. Depending on the objectives of each program, they can be used for training, development of physical qualities, psychological training, pedagogical control, which is much more important for the process of physical education.

They will allow you to capture data from various sensors, display indicators on a color display, store information in cloud storage. The result of such devices will be a bio-journal with data on the state of physical fitness of a particular student. The device measures body temperature, heart rate, blood pressure, oxygen content, monitors sleep phases and stress levels, and has a fairly wide range of functionality: speedometer, altimeter, pedometer, calorie counter.

Lifelog records data on physical and social activity, as well as data on leisure. For example, you can see how long you are in it

Progressive developments in computer technology used in physical education to assess physical fitness were once made by the Cooper Institute and the National Sports and Physical Education Association (NASPE). The developed computer program (Fitness gram / Activiti gram) is designed to assess the aerobic capacity of the body, determine body composition, body mass index, fitness indicators [4].

It is worth noting that in today's world, most young people have fitness bracelets that can be used in any sport. Most of all models look quite simple and identical to each other, but for each gadget, many different fitness programs have been developed. 
Fitness bracelet applications are specialized utilities that allow you to synchronize various information from fitness bracelets to smartphones using a wireless connection called bluetooth. Yes, the most popular fitness programs: Run Keeper, Nike + Run Club, Mi FIT, Misfit, Microsoft Health, etc.

These programs are multifunctional, most of which relate to determining the state of health, level of physical development and physical fitness of students and those involved in sports, technical and tactical training of young athletes and more. At the same time, there are not enough programs that would be aimed at determining the individual level of motor activity, taking into account anthropometric indicators, physical fitness and morphofunctional indices.

So, today, there are many scientific works, both domestic scientists and foreign authors, which define the essence, structure and functions of physical education, its impact on the systems and organs and importance in life, made an analysis of the current state of physical culture in country and identified constructive measures to improve its situation.

However, the theoretical foundations of the modern system of physical education developed by the authors, the content of the program to improve motor activity of modern youth in higher pedagogical school are based on traditional, outdated provisions, without the introduction of modern information technology, which does not solve the problem of forming students the need for physical education classes and improving the level of physical activity.

As a result of the analytical work there was a need to develop a new method for determining the individual level of motor activity using modern information and communication technologies and its implementation in the process of physical education of students of higher education. The transition to a high-tech information society, in which the quality of human kinesiological knowledge and the level of education and culture acquires special significance for the social and economic development of the country, entails the development of modern information and communication technologies to control motor activity.

Conclusions. The analysis of scientific and methodical literature confirms the importance of pedagogical control in physical education of students of higher education institutions not only in theoretical but also in practical terms. It is established that there are many approaches and proposals for finding effective ways to improve the systems of control and evaluation of educational achievements in physical education classes. At the same time, the analysis of practical achievements of well-known specialists in the field of physical education indicates the imperfection of modern methods of control.

Important is the problematic issue of the abolition of assessment and control of educational and practical achievements in the process of physical education, which leads to reduced attendance, motivation and reduction of their status, deterioration of the physical condition of youth, reduced level of physical activity. At the same time, the scientific literature, which highlights the problem of pedagogical control in the physical education of students of higher education institutions, is empirical in nature and is implemented without appropriate metrological justification.

Therefore, there is a question in the development and implementation of a system of control and evaluation of physical activity, which would meet the modern requirements of the educational process and have an effective impact on improving the status of physical education and attracting young people to exercise.

The rapid process of informatization of society and education in general, require the implementation of the latest information and communication technologies in the field of physical education. The analysis of psychological and pedagogical, scientific literature on the researched problem allowed to reveal the absence of the developed model of application of information technologies in the process of physical education of students, to reveal the problem of lack of software complexes which carry out process of physical education at the modern scientific and technical level.

\section{References}

1. Bubley T. (2016) Features of planning and organization of physical education lessons for students with impaired health: status and prospects // Scientific Journal. Series 15. "Scientific and pedagogical problems of physical culture (physical culture and sports)". Issue 3K 2 (71) 16. K .: Published by NPU named after M. Drahomanov. 53-55 p.

2. Griban, G., Tymoshenko, O., Arefiev, V., Sushchenko, L., Domina, Zh., Malechko, T., Zhuravlov, I., Tkachenko, P., Baldetskiy, A., Prontenko, K. (2020). The role of physical education in improving the health status of students of special medical groups. Wiadomości Lekarskie, 73 (3), 534-540. doi: 10.36740/WLek202003125.

3. Shaposhnikova, I., Korsun, S., Arefieva, L., Kostikova, O., Serhiienko, V., Korol, S., Riabchenko, V. (2021). Analysis of students' somatic health and emotional state during sports games classes. Wiadomości Lekarskie, 74 (3 p.II), 608-612. doi: 10.36740/WLek202103208.

4. Tymoshenko, O., Arefiev, V., Domina, Zh., Malechko, T., Bondar, T., Tymchyk, M., Pliushchakova, O., Riabchenko, V., Griban, G., \& Prontenko, K. (2021). Exercise machines in speed and coordination development among students playing basketball. International Journal of Human Movement and Sports Sciences, 9(2), 347-355. doi: 10.13189/saj.2021.090224. 